\title{
The GIIPS crisis in the context of the European Monetary Union: a political economy approach
}

\author{
Nicholas Magnus Deleuse Blikstad* \\ Giuliano Contento de Oliveira ${ }^{\dagger}$
}

\begin{abstract}
The GIIPS crisis (Greece, Italy, Ireland, Portugal, and Spain) has been deep and resistant. To date there have not been clear signs of consistent recovery from these economies, with the only exception being Ireland, that has experimented with a longer lasting economic recovery process in recent times. The aim of this paper is to discuss the GIIPS crisis in light of the European integration project. It is argued that this crisis has resulted from two simultaneous processes: on the one hand, it has resulted from the growing internal imbalances that occurred over the economic expansion period; on the other hand, it has resulted from the rigidities imposed by the institutional arrangement of the European Monetary Union. It has been concluded that the consistent economic recovery of these economies requires an aggregate demand stimulus for them, a condition that in turn requires the implementation of countercyclical economic policies.
\end{abstract}

Keywords: GIIPS crisis; European Monetary Union; New Consensus Macroeconomics.

JEL Classification: F00; F02; F41; F42; F45.

PhD student in Economics at the University of Campinas, Institute of Economics. E-mail: nicholas.blikstad@gmail.com

+ Professor of the Institute of Economics at the University of Campinas. E-mail: giueco@unicamp.br 


\section{Introduction}

The European crisis began under the instability effects triggered by the global financial crisis that arose in 2008. The growing trade and investment relations of the European Union, both from the interregional and intraregional point of view, combined to broaden the transmission channels of the crisis that originated in the American subprime market.

Particularly for the economies of the Eurozone, the effects of the crisis were enhanced by the institutionality of a common currency, which hinders the region's countries in carrying out countercyclical economic policies. From the point of view of government debt, the most vulnerable economies have been more adversely affected, namely Greece, Italy, Ireland, Portugal, and Spain, the so-called GIIPS ${ }^{1}$ countries.

In this sense the paper aims to analyse the GIIPS crisis in the context of the European Monetary Union project, from a political economy approach, highlighting the economic theory that served and legitimised the constitution of the Eurozone. It is affirmed that the restrictions imposed by the Eurozone institutions, in the context of the high capital mobility prevalent in the region, resulted in structural problems in these economies, those being: 1) the generation and growth of internal imbalances inside the group, during the period of economic expansion (2000-2007), between the center and the periphery of the region; 2) the deepening of the effects of the financial global crisis triggered in 2008, the epicenter of the crisis being the so-called GIIPS nations from 2010 onwards; and 3) the deepening of the crisis, due to recommendations made by the European authorities.

Therefore, it is maintained that the Eurozone crisis, although resulting from the operating logic of contemporary liberalised and deregulated markets, was deepened by the institutionality that resulted from the constitution of the common currency bloc.

The paper is organised in to three sections, besides the introduction and the conclusion. At first, we discuss the European integration process and the constitution of the Eurozone in 1999. Secondly, we analyse the expansion period and the GIIPS crisis.

\footnotetext{
${ }^{1}$ The acronym "PIGS" was originally used by the international press to designate the Southern Europe countries, i.e., Portugal, Italy, Greece, and Spain. The pejorative acronym "PIGS" has been used to indicate that after the crisis in Europe, the low dynamism of this group of countries was due to irresponsible public policies. Thus, after the outbreak of the crisis in Europe, Ireland was incorporated into this group of countries, in order to contemplate all those with significant imbalances in public accounts.
} 


\section{The European integration project and the structural problems in the Eurozone}

This section discusses the main aspects of the European integration project, which culminated in the creation of the euro area, highlighting the period before the GIIPS crisis.

\subsection{The European integration and the Euro}

According to the conventional orthodox approach, motivations associated with regional integration are related to economic efficiency gains arising from the disposal of commercial and financial barriers in a particular region. It is understood that regional integration can result in several benefits, such as: 1) the generation and expansion of scale economies; 2) better allocation of resources; 3) increased productivity, inciting competition; and 4) an increase in the rate of economic growth. Economic disparities among the member countries are not the obstacle in this approach, for market mechanisms are sufficient to eliminate them. The liberalisation of markets, in turn, implies the targeting of these resources for investments in undeveloped countries, with the subsequent modernisation of productive structures, increasing productivity, and reducing the differential per capita income between countries of a given bloc (Amado and Mollo, 2004; Robson, 1998).

The several stages of the European integration project, with the formation of the European Coal and Steel Community (ECSC) in 1951, the Treaty of Rome in 1957, and its amendment, in 1986, with the Single European Act (SEA), contributed to the creation of a customs union in the late 1960s, and to the formation of a common market in the early 1990s, aiming to obtain the indicated economic gains.

However, between the immediate post-World War II period and the end of the 1960s, the motivations for seeking economic efficiency were subjected to the maintenance of peace, reconstruction of the economies, and political integration in the continent, prioritising the expansionist and autonomous economic policies and the narrowing of the relations between France and Germany. Certainly, war memories and the precarious situation of the continent at the beginning of 1950s were determinant in this process. With the high rate of the world economy growth during the 1950s and 1960s, particularly in Europe, associated with the international order of the Bretton Woods system, the European integration process had progressed without significantly compromising the autonomy and national objectives of its countries. It was possible, therefore, to develop the integration 
process while maintaining the autonomy of the economic policy, which was aimed at maintaining jobs and income, under the predominance of the Keynesian consensus (Arestis et al., 1999; Judt, 2005).

In the 1970s, greater distance from the horrors of war, economic instability, and stagflation, along with the increased international competition between the USA, Japan, and Europe, all contributed to an ideological inflection within the continent, in the sense that liberalising policies started to prevail, to the detriment of economic policies aimed towards internal goals. From the late 1970s and early 1980s, unlike the previous period, the main objective of the European regional integration project has become the pursuit of economic efficiency at any cost, in line with the conventional orthodox approach of regional integration. According to Helleiner (1994), the change to market-oriented policies was, in addition to the economic instability in the 1970s, a result of the rise of pro-market intellectuals: the emergence of a coalition of interests of private financial institutions, corporations, and official agencies to promote such ideals.

In addition, the Bretton Woods crisis and the consequent conformation of a new international monetary and financial (dis)order, marked by floating exchange rates and high capital mobility, raised difficulties for the compatibility between regional integration and the autonomy of member countries' economic policies, due to the need of coordinating national economic policies between these countries.

That became clear with the unsuccessful attempt to establish a monetary union in the early 1970s, through the Werner Report (1970). According to this report, the evolution of the economic integration and the greater interconnection among the national economies of the European Economic Community (EEC), within a context of changes in the international monetary system, generated a situation in which economic imbalances of a country affected other members quicker and more directly. The establishment of a monetary union thus implied the need for greater coordination between economic policies, and the transfer of responsibilities from the national level to the community level (Arestis et al., 1999; Eichengreen, 2007).

Aiming to deal with the exchange rate instability problem, in 1972 the "European currency snake" was created ${ }^{2}$, but given the economic instability and

${ }^{2}$ Exchange anchor collective system, according to which the European Economic Community's countries, in addition to Norway and Sweden, agreed to limit variations in their bilateral exchange rates originally at $4.5 \%$ (2.25\% up and $2.25 \%$ down), considering the other signatory countries of 
the lack of consensus regarding the conduction of market-oriented economic policies, especially regarding monetary policy, it failed in organising the coordination of these policies in order to maintain exchange rate stability (Bakker, 1996). There was a new attempt in 1979 with the European Monetary System (EMS), in order to fix and restrict the fluctuation between currencies of the European Community, in addition to reducing inflation rates, achieving success with these two goals throughout the 1980s (Eichengreen, 2000). During this period, the use of capital control was allowed so the coordination of economic policies could achieve the objective of maintaining exchange rate stability and contributing to the integration of markets in goods and services.

For the ideological inflection in the continent and to support the need for the coordination of the bloc's economic policies, the rise of the German leadership throughout the 1970s was crucial, imposing changes toward the adoption of market-oriented economic policy and implementing it solely and exclusively to keep the price index low and stable over time. For Bibow (2013), in Germany, in the early 1980s, Keynesianism was officially banned, with fiscal austerity and orthodox economic theories becoming unchallenged dogmas.

The reorientation of French economic policy in 1983, aligning to Germany in the coordination of market-oriented economic policies, after the failure of the Mitterrand's expansionist policy (1981-83), was extremely important to consolidate and disseminate the consensus regarding the use of economic policies in the continent, contributing to the success of the EMS and to the advancement of the monetary integration process. In this movement, the implementation of expansionist and unilateral economic policies would no longer be possible, considering that one could have less autonomy outside the EMS. At the same time that Germany managed to bring back its most important ally to the integration process, the French experience was an example for other countries in the region (Bakker, 1996; Eichengreen, 2000; 2007; Judt, 2005).

Having France as an ally, Germany started defending liberalisation and financial deregulation, contributing to a change in the propositions from the European Commission. The latter, indeed, after the troubled decade of 1970, started defending the liberal-conservative project, based on the liberalisation and deregulation of markets, especially in the goods and services markets as well as in the financial markets. For the European Commission, more coordination of the economic policies would enable the evolution in this process, seeking the benefits

the agreement. The "snake", however, was unable to make the exchange rate stability at the regional level feasible, given the prevailing turbulence (Eichengreen, 2000, p. 202-18). 
of financial integration, with greater allocative efficiency of resources (Bakker, 1996; Eichengreen, 2007).

According to the European Commission, the EMS, the creation of an environment of economic convergence and monetary stability, along with the establishment of the common market, would be the foundation for the consolidation of the monetary union process. To that end, it was necessary to build an institutional apparatus to suppress the possibility of internal nominal exchange rate variations in the bloc, as well as creating a single financial market. In 1988, at the European Summit, the establishment of a committee to study and propose concrete stages that would lead to economic and monetary union in the region was decided. The Delors Report was created in 1989, and had great influence on the Maastricht Treaty of 1993. The latter, in turn, determined the format of the European economic and monetary union process, resulting in the creation of the Eurozone in 1999 - the group of countries that started using the common currency, the Euro (Arestis et al., 1999; Delors Committee, 1989). The conventional orthodox economic theory has, undoubtedly, had great influence on this integration process, particularly regarding the monetary union, understood as a crucial factor for the success of the project.

In this context, the theory of Optimum Currency Areas (OCA) was introduced in the 1970s. According to this theory, the lower degree of autonomy of the countries regarding economic policy was a cost for joining a monetary union (Corden, 1972; Ishiyama, 1975). This became clear with the failure of economic policy coordination throughout that decade. Very important for the inflection of this position was the guidance of the orthodox economic theory over the 1970s and 1980s, under the aegis of the rational expectations theory, being supply-side oriented, and to the importance of credibility and the adoption of rules for the economic policy (Bernanke and Mishkin, 1997; Kydland and Prescott, 1977).

This movement in macroeconomic theory resulted in so-called New Consensus Macroeconomics (NCM), which advocates the adoption of an economic policy in which the single goal of monetary policy is price stability, through an independent monetary policy, considering fiscal policy subordinated to the first ${ }^{3}$. Influenced by NCM, the New OCA (in the late 80s and 90s) started conceiving the loss of autonomy of economic policies by adopting a common currency as a benefit (De Grauwe, 2010; Robson, 1998; Tavlas, 1993). The benefits pointed out both by the OCA and the New OCA are based on potential gains in

${ }^{3}$ See Arestis (2007). 
economic efficiency from the monetary union, in addition to the greater scope of the use of the national currency, the elimination of speculative capital flows, and the economy in foreign-exchange reserves.

Another important benefit of the monetary union pointed out by New OCA is regarding the endogeneity criterion. In this perspective, we should not consider only the ex-ante situation, but also the conditions that may be conquered ex-post, with changes in the expectations of agents throughout the process of monetary union establishment (Alesina, Barro and Tenreyro, 2002; De Grauwe and Mongelli, 2005; Frankel and Rose, 1997). This means to state that, through this theoretical premise, the establishment of a monetary union would endogenously create conditions for the convergence of variables necessary for its success.

The endogeneity criterion and the view that in an integrated region the international capital flows would migrate from the most developed countries to the least developed ones were powerful rhetorical instruments to establish a monetary union formed by heterogeneous countries, such as the case of the Eurozone. The influence of this theoretical conception on the establishment of the single currency was evident in the European Commission (1990), regarding the costs and benefits of joining a monetary union, as well as in Issing et al. (2004) and Scheller (2006), in relation to the ideal way of conducting the monetary policy by the European Central Bank (ECB).

\subsection{The problems imposed by the institutionality of the common European currency}

As analysed by the Werner Report (1970), three conditions would be required for the establishment of a monetary union, namely: 1) total and irreversible conversion of currencies (monetary sphere); 2) full liberalisation of capital movements and financial market integration (financial sphere); and 3) elimination of nominal exchange rate movements, irreversibly (exchange rate sphere). The first had already been achieved and the second would be completed in the early 1990s, with the Single European Act (Delors Committee, 1989).

The third condition would be achieved through a gradual transition to the common currency. Throughout this transition period, according to the European authorities, both a convergence of nominal variables (prices, budget deficit, public debt, and interest rates) among countries, and a greater commitment to coordinate economic policies would be required as a way to making the monetary union feasible. 
Once the single currency had been adopted, the bloc's monetary policy would be conducted by the European Central Bank (ECB), the supranational institution independent of member countries, strongly influenced by the structure of the Bundesbank and the NCM, with the single goal of ensuring a low and stable inflation rate. That is, a single monetary policy for the bloc. The fiscal policies of each of the Eurozone countries would be maintained under the responsibility of national authorities, but subject to restrictive rules of the Stability and Growth Pact (SGP) and to the supranational monetary policy.

It is noteworthy that the institutional restrictions resulting from this way of establishing the Eurozone, especially regarding the limits imposed for the implementation of autonomous and countercyclical economic policies, in addition to the logic of liberalised and deregulated financial markets, were determinant for the creation of the conditions, the severity, and the extension of the Eurozone crisis, especially in GIIPS. Such restrictions has allowed the evolution of internal imbalances within the bloc, between the center and periphery, concerning private debt, external position, and internal demand.

Therefore, there was a significant reduction in the degree of autonomy of national economic policies within the monetary union. According to Oliveira, Deos and Wolf (2012) , the form that this process assumed radically restricted the ability of countercyclical economic policies on the part of the member countries, due to the lack of a fiscal institutionality to do so. In addition, euro institutionality has created difficulties for National States of the bloc to handle financial crises because of the lack of monetary sovereignty, due to the inability of the State to issue its own currency. That is, the State is unable to issue the currency capable of liquidating its debts. Hence, according to Toporowski (2013, p. 572), "The Eurozone has a central bank without a government, governments without central banks, and banks without an effective lender of last resort".

In fact, when restricting its actions according to the conventional orthodox theory, as well as legitimising them based on it, Germany has forged a bloc in which joint interests of the countries were not considered; such countries would be guided by a common policy, which would fatally cause problems in times of crisis, especially for the European peripheral countries and/or those with more vulnerability within public finances (Aglietta, 2013).

According to the official doctrine inherent in the formation of the Eurozone, once the nominal convergence is performed, the financial integration would create an efficient economic area, contributing to increase investments and to the diversify the productive structure of the least developed countries, followed by 
increased productivity. All these transformations, together, would enable the real convergence of the periphery of the region in relation to the developed countries. This would raise competitiveness and would provide accelerated growth in less developed economies (Aglietta, 2013).

A point to be highlighted is that this nominal convergence has enabled a fragile real convergence, highly susceptible to instability and crises. In practice, what we observed was a huge inflow of capital only during the expansion period (2000-2007), from the center to the periphery, predominantly directed to the nonexporters sector, such as services and construction, especially in the case of Spain and Ireland. This strongly stimulated consumption, resulting in increased private debt. When the crisis occurred, an intense reversal of the incipient process of income convergence verified during the favourable period was observed (Aglietta, 2012, 2013; Oliveira, Deos and Wolf, 2014).

Regarding the issue of the endogeneity criterion of the New OCA, reality showed a dynamic towards the opposite direction. Indeed, in the first decade of the existence of the Eurozone, contrary to what was predicted by European authorities, an increase of the heterogeneity of the production structures of the bloc countries was observed, in addition to a sectoral specialisation. As stated by Priewe (2012), divergences and not convergences have been endogenously processed. This is mainly because: 1) unit costs of work and different inflation rates, creating imbalances in wage costs between the countries, which had relevant effects in terms of competitiveness and productivity differentials of member countries (Arestis and Sawyer, 2011; Bibow, 2012; Flassbeck and Lapavitsas, 2013; BresserPereira and Rossi, 2015); 2) polarisation of productive structures, with increased industrial development and diversification in center countries and regression and specialisation in GIIPS (Dullien, 2010; Miranda, 2014); and 3) the adoption of a single monetary policy for the Eurozone, considering the existence of inflation rate differentials. This resulted in different real interest rates, affecting central and peripheral economies in a restrictive and expansionary way, respectively, regarding the components of internal demand (Toporowski, 2013). These factors made the process of real convergence of bloc economies vulnerable to setbacks, and allowed the evolution of internal imbalances in the region. 


\section{Expansion and crisis in the Eurozone}

This section aims to analyse the dynamics of the economic expansion (20002007) and the Eurozone crisis (2007-2013) periods, considering the elements discussed in the previous section. Initially we discuss the evolution of imbalances in the Eurozone between the central and peripheral region during the expansion period, and the characteristics of the adjustment process after the outbreak of the global financial crisis in 2008. In addition, the section highlights the difficulties for recovering growth in the region, both because of the regional dynamics and the restrictions on the use of autonomous countercyclical economic policies due to the restrictions imposed by the euro institutionality. Finally, we analyse the vision of Eurozone authorities on the determinants of the crisis and recommendations for its overcoming.

\subsection{The differentiated dynamics between GIIPS and Germany}

When analysing the existence of financialised capitalism, Hein (2012) envisions three possibilities for the dynamics of the Eurozone economies over expansion periods, namely: 1) debt-led consumption boom, in which the growth of aggregate demand occurs by increasing the debt toward consumption and a relative stagnation of investment, which would be the case of Ireland, Greece, and Spain; 2) export-led mercantilism, in which the advance of exports are essential to the performance of the economy, reflecting the dynamics of the German economy; and 3) domestic demand-led, in which the dynamism of the economy is led by domestic demand, but without the strong evolution of the debt of households towards finance consumption, as in the case of Portugal and Italy. For the author, the different behaviour of growth strategies between GIIPS and Germany, with the first focusing on consumption and the latter based on exports, contrary to what the Lisbon Strategy advocated, is essential to the evolution of imbalances regarding economic growth, private debt, and the external position of economies.

The economic expansion period in the Eurozone, until mid-2007, was marked both by a strong international liquidity and by low interest rates in GIIPS, due to the convergence process between long-term interest rates verified between the economies of the region (Oliveira, Deos and Wolf, 2012).

Table 1 shows the GDP components of GIIPS and Germany, highlighting the different performances of the countries over the expansion period. We may verify a strong dynamism of the GDPs of Spain, Ireland, and Greece, largely conditioned by internal demand. Therefore, it was a dynamic of growth of 'debtled consumption boom' type, considering the taxonomy proposed by Hein (2012), 
with growth being pulled by the expansion of household, government, and investment (gross capital formation) expenditures ${ }^{4}$, which were enhanced by the increase in private debt.

While the GDP growth of Spain, Greece, and Ireland was much higher than the Eurozone average between 2000 and 2007, Germany's was below the average of the bloc, with low dynamism of GDP internal determinants and highlighting the expansion of exports, with the external sector being predominantly responsible for German GDP growth. This had strong implications for the evolution of internal imbalances of the bloc. Regarding Portugal and Italy, the low dynamism of their GDP is highlighted, but with the dynamics of internal demand a little higher than in Germany.

With the global financial crisis triggered in 2008 and the crisis of sovereign public debt of GIIPS in 2009, there was a pronounced decline of international liquidity, a reversal of capital flows (which, before, flowed from the center to GIIPS), and the end of the perception that the risks of sovereign public debts of different economies of the Eurozone were similar. This had strong negative impacts on the economic growth, as we can observe in Graph 1 and Table 2.

Table 1. Real growth rate of GDP components (in percentage), selected countries of the Eurozone (2000-2007)

\begin{tabular}{lccccccc}
\hline \multicolumn{1}{c}{ GDP } & Germany & Spain & Portugal & Italy & Greece & Ireland & Eurozone \\
\hline $\begin{array}{l}\text { Internal } \\
\text { demand }\end{array}$ & 3 & 35 & 7 & 9 & 36 & 46 & 13 \\
$\begin{array}{l}\text { Households' } \\
\text { consumption }\end{array}$ & 4 & 27 & 11 & 7 & 32 & 41 & 11 \\
$\begin{array}{l}\text { Government's } \\
\text { consumption }\end{array}$ & 4 & 42 & 15 & 9 & 36 & 45 & 14 \\
$\begin{array}{l}\text { Gross Capital } \\
\text { Formation }\end{array}$ & 2 & 49 & -7 & 16 & 47 & 62 & 17 \\
$\begin{array}{l}\text { Export of goods } \\
\text { and services }\end{array}$ & 64 & 31 & 38 & 24 & 32 & 49 & 40 \\
$\begin{array}{l}\text { Import of goods } \\
\text { and services }\end{array}$ & 40 & 57 & 25 & 28 & 44 & 48 & 37 \\
\hline GDP & 10 & 28 & 9 & 8 & 32 & 40 & 14 \\
\hline
\end{tabular}

Source: Eurostat (2017). Elaborated by the authors.

\footnotetext{
${ }^{4}$ In the case of Ireland and Spain, in spite of growth rates of fixed gross capital formation, these investments are mainly concentrated on the service sector, more specifically on the construction sector, and not on productive investment. The very evolution of the construction sector was essential, with the importance of the appreciation of real estate prices and the wealth effect to stimulate consumption and the economy.
} 
Graph 1. GDP annual percentage variation: GIIPS and Germany (2000-2015)

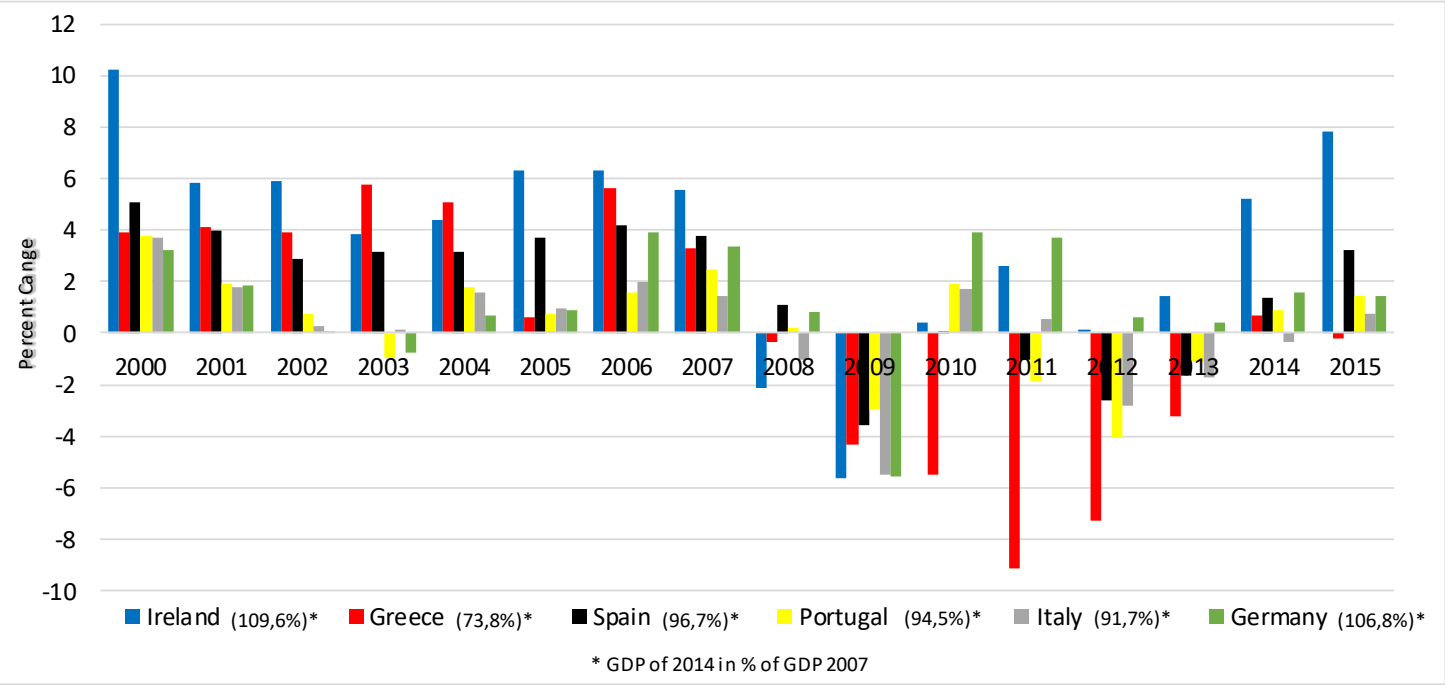

Source: IMF (2017). Elaborated by the authors. Note: for the year 2015, IMF projection.

For Spain, Greece, and Ireland, with economic growth marked by the deepening of the private debt over the expansion period - and also for Portugal and Italy -, there was a strong GDP retraction in 2009. Thereafter, the GDP variation of these economies continued showing negative variations or started growing very little, with the exception of Ireland in the most recent period, from 2013 onwards, due to the dynamism of tradable sectors ${ }^{5}$. In Greece, surely the most extreme case of the GIIPS crisis, the 2016 GDP was still far below the 2007 GDP level. Among the other economies of GIIPS, in 2016, only Ireland had a GDP higher than that verified in 2007. As shown in Table 2, only Germany and Ireland showed a positive variation of GDP between 2007 and 2016. Excluding Ireland, the GIIPS had a significant contraction in the gross capital formation.

The point to be highlighted is the economic performance differential between GIIPS and Germany during the period of expansion, and the difficulties for the recovery of GDP growth - except for Ireland -from the outbreak of the crisis. An essential factor to enable this dynamic in the expansion period, one of the results of the structural problems discussed in the previous section, was the significant increase in the debt of the private sector in GIIPS to stimulate internal demand. Surely this movement was accompanied by a gradual weakening process of the financial structure of these economies, making it explicit regarding the

\footnotetext{
${ }^{5}$ About Ireland's economic recovery in the recent period and the importance of the tradable sector in this process, see Fitzgerald (2014).
} 
reversal of optimistic expectations, and it can be considered a typically Minskyan phenomenon ${ }^{6}$.

Table 2. Average growth rate of GDP components (in percentage), of selected countries of the Eurozone (2007-2016)

\begin{tabular}{lccccccc}
\hline GDP Components & Germany & Ireland & Greece & Spain & Italy & Portugal & Eurozone \\
\hline Households' & 10 & 1 & -22 & -5 & -5 & -2 & 5 \\
$\begin{array}{l}\text { consumption } \\
\text { Government's }\end{array}$ & 20 & -1 & -25 & 7 & -2 & -6 & 11 \\
$\begin{array}{l}\text { consumption } \\
\text { Gross capital }\end{array}$ & -1 & 59 & -70 & -28 & -29 & -33 & -10 \\
formation & & & -1 & 25 & 6 & 34 & 29 \\
$\begin{array}{l}\text { Exports of goods } \\
\text { and services }\end{array}$ & 28 & 82 & -34 & -12 & -3 & 12 & 24 \\
$\begin{array}{l}\text { Imports of goods } \\
\text { and services }\end{array}$ & 31 & 63 & -33 & -12 & -7 & -4 & 5 \\
\hline GDP & 9 & 34 & -26 & -1 & -7
\end{tabular}

Source: Eurostat (2017). Elaborated by the authors.

Graph 2 presents the consolidated debt of the private sector in relation to GDP, for the cases of the GIIPS countries and Germany, between 2001 and 2015. We may observe that between 2001 and 2007 this indicator increased 82 percentage points (p.p.) in Spain, 42 p.p. in Greece, and 58,7 p.p. in Ireland. This indicator continued increasing, although in a rather inferior pace than the rate verified in the immediately preceding period, between 2008 and 2009 in Portugal, Spain, and Italy, on the one hand, and between 2008 and 2012 in Greece and Ireland, on the other. In Germany, there has been a clear trend of decline of private debt in relation to GDP between the beginning and the end of the period considered, highlighting the importance of the external sector for the country and the low relevance of internal demand.

In GIIPS, the evolution of debt of households, as a percentage of net disposable income, between 2002 and 2012, makes clear the difficulty of recovering economic growth as pulled by household consumption. Graph 3 shows that since 2007 the efforts to decline household debt have not achieved good results, highlighting the cost in economic terms of giving up internal demand as a driver of GDP, following the deflationary recommendations of European authorities. The rise in unemployment and the subsequent wage compression combine to hinder a consistent process of reducing the debts of households in relation to the available net wage.

This situation shows the typical problem of the "fallacy of composition", as shown by Keynes (1936). That is, the increase of the liquidity preference level

${ }^{6}$ About the financial instability hypothesis of Hyman Minsky, see Minsky (1982; 1986). 
became detrimental along with the credit conditions and increased the debt to GDP ratio, due to the worsening financing conditions, and consequently, the decrease in spending decisions and GDP. The widespread search for deleveraging by the economic actors has contributed in worsening the problem of household and corporate indebtedness, with adverse effects on the regional economies, especially in GIIPS, as showed by Athanassiou (2012). Therefore, with the exception of Greece, which had already shown problems in their public accounts, in the other economies of GIIPS the sovereign debt crisis resulted preponderantly from a private debt crisis that occurred before the global crisis deflagration. The deleveraging movement incurred unsustainable economic effects, by making necessary countercyclical economic policies and lender of last resort policies, in a strongly unfavourable context in terms of financing conditions, causing the sovereign debt crisis in these countries. According to De Grauwe (2010, p.2)

A consensus seems to be building up in Europe identifying the failure of the Stability and Growth Pact (SGP) to keep a lid on national budget deficits and debts as the root cause of the government debt crises in the eurozone. I want to argue that, with the exception of Greece, the reason why countries got into a sovereign debt crisis has little to do with the poor performance of the SGP. The root cause of the debt problems in the eurozone is to be found in the unsustainable debt accumulation of the private sectors in many eurozone countries.

Over the expansion period, the fast pace of the GDP growth of GIIPS, enhanced by the significant increase in private debt; the low dynamism of internal demand of the German economy and its growth strategy largely based on increased exports; the regressive specialisation of the productive structure of GIIPS; and the initial deficit position in the current account of the balance of payments of those countries at the time of the Eurozone establishment, in 1999, resulted in a dynamic of external vulnerability intensification of GIIPS, as shown in Graph 4. Although the structural problems have been hidden over the economic expansion period, due to the behaviour of international capital flows, with the reversal of these flows the fragilities of the euro's architecture became explicit (Belluzzo, 2013; Guttmann and Plihon, 2010). 
Graph 2. Private sector debt* consolidated in relation to GDP: GIIPS and Germany (2001-2015)

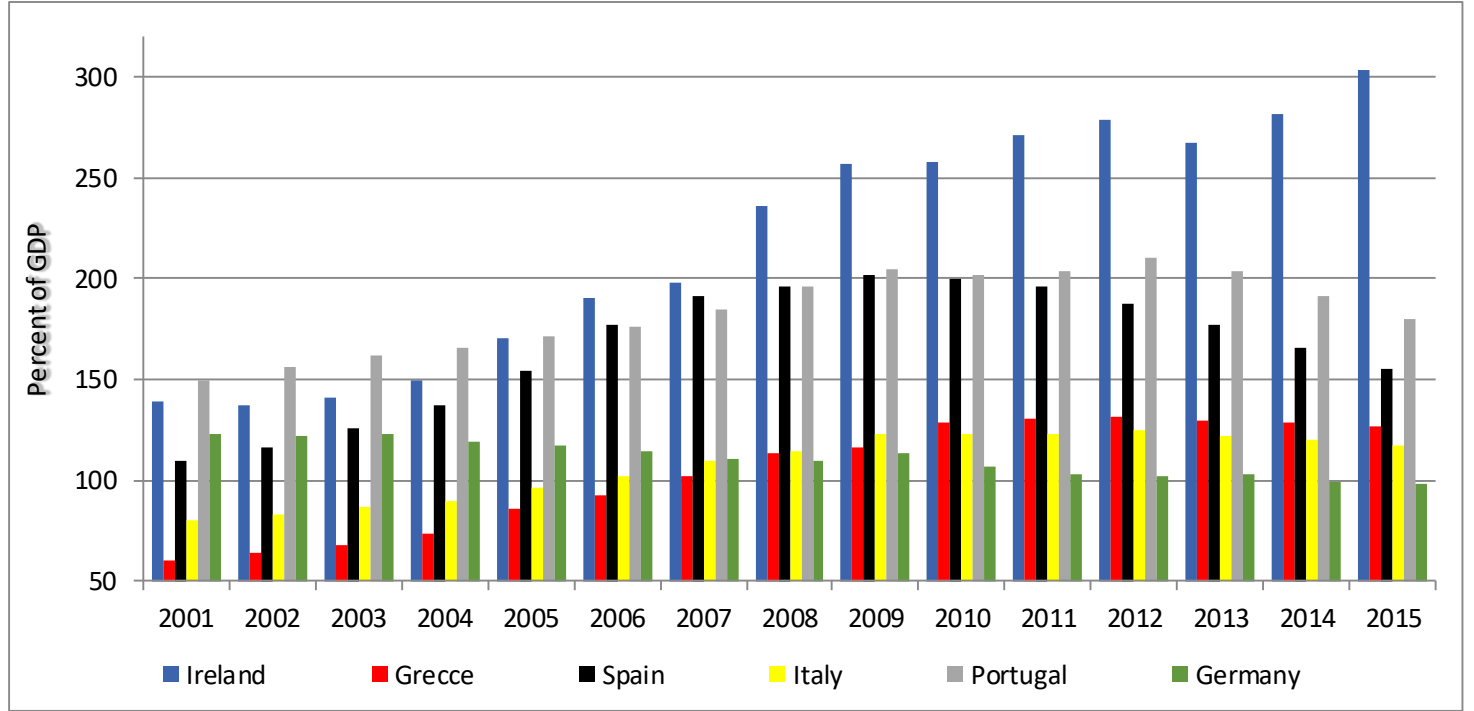

Source: Eurostat (2017). Elaborated by the authors. Note: * Households, non-profit companies serving the households, and non-financial corporations.

Graph 3. Debt of households, as a percentage of net disposable income, GIIPS (2002-2014)

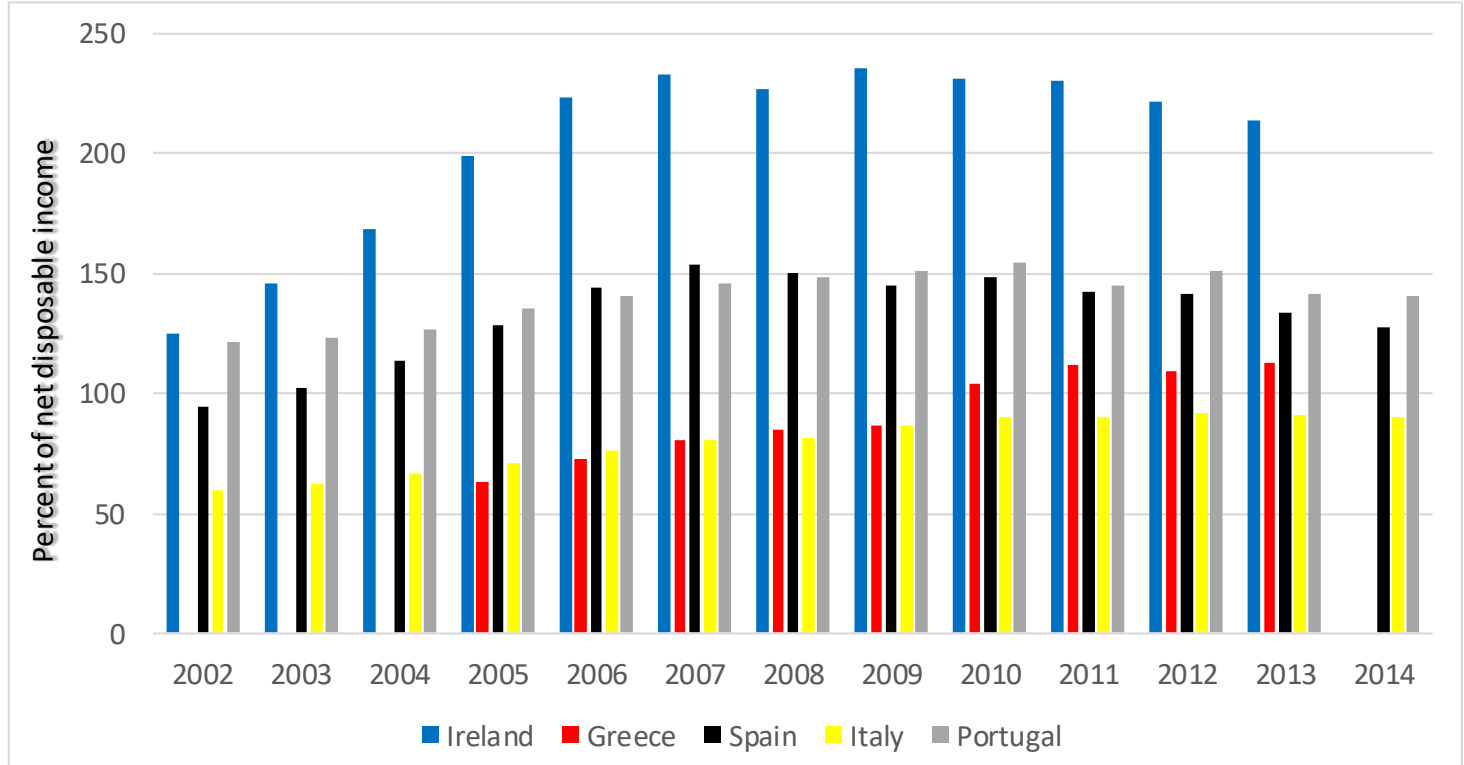

Source: OECD (2016). Elaborated by the authors. 
Graph 4. Net profit on a current account (\% of GDP): GIIPS and Germany (20012016)

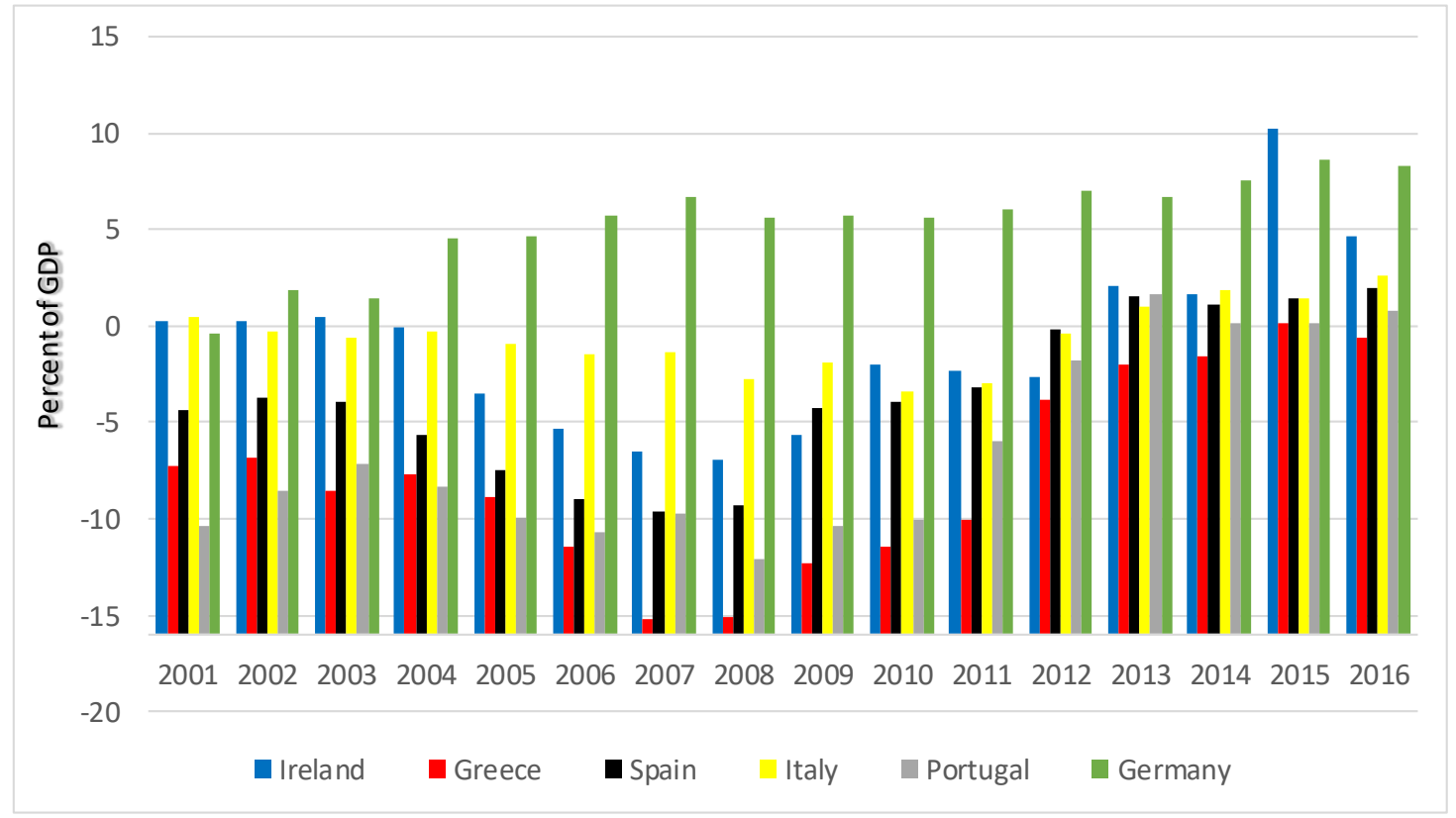

Source: Eurostat (2017). Elaborated by the authors.

Regarding the position of the current account of the balance of payments, Graph 4 allows the verification of two behaviour patterns. On the one hand, Germany, with the accumulation of surpluses throughout the expansion period, maintaining this position after the crisis. On the other hand, the GIIPS countries that had growth dynamics pulled by internal demand, stimulating imports, showed a strong deterioration in the position in the current account over the expansion period. After the 2008 crisis, before the significant deflationary adjustment, there was a trend of improving the position in the current account of GIIPS, but remaining negative until 2013 for most of them. It should be pointed out, however, that by following the recommendations of the European authorities, this improvement in the case of GIIPS has occurred through recessive adjustment, a condition that contributed to the stagnation of internal determinants of the economic growth and to the unfeasibility of the implementation of countercyclical policies.

Hence, there is no evidence for recovering autonomous expenditures or those of private consumption in GIIPS. European authorities believe that this deflationary process may create conditions for the development of the exports of these countries, stimulating the economies, using Germany's case as an example to be followed. However, this strategy makes the recovery of the economic growth of these economies unfeasible and ends up, therefore, increasing unemployment and deepening the social crisis even more. 
Graph 5 presents the investment net external position of GIIPS and Germany. There is a clear trend of a relevant increase in the net external liability of Spain, Greece, and Portugal, between 2001 and 2016. These economies have received a lot more foreign investment than they have made, in the form of foreign direct investment, bank loans, and portfolio investments. Such inflows were also required to equalise the external accounts of these economies, before their high deficits in the current account, as previously mentioned. In the case of Ireland, there was a significant increase in net external liability in 2008, with the deterioration of net international position since then. The banking crisis and the worsening of financing conditions induced a significant reduction in the portfolio investments held by Irish people abroad, which, along with the GDP contraction, explains the strong increase in the country's net external liability between 2007 and 2008. In Italy, the indicator had a certain worsening over the period considered, but nothing comparable with the rest of GIIPS, in level terms. In the case of Germany, on the other hand, there has been an improvement in the net external position of investment throughout the period, enhancing the existing asymmetry in relation to GIIPS.

Graph 5. Net external position of investment (\% of GDP): GIIPS and Germany (2001-2016)

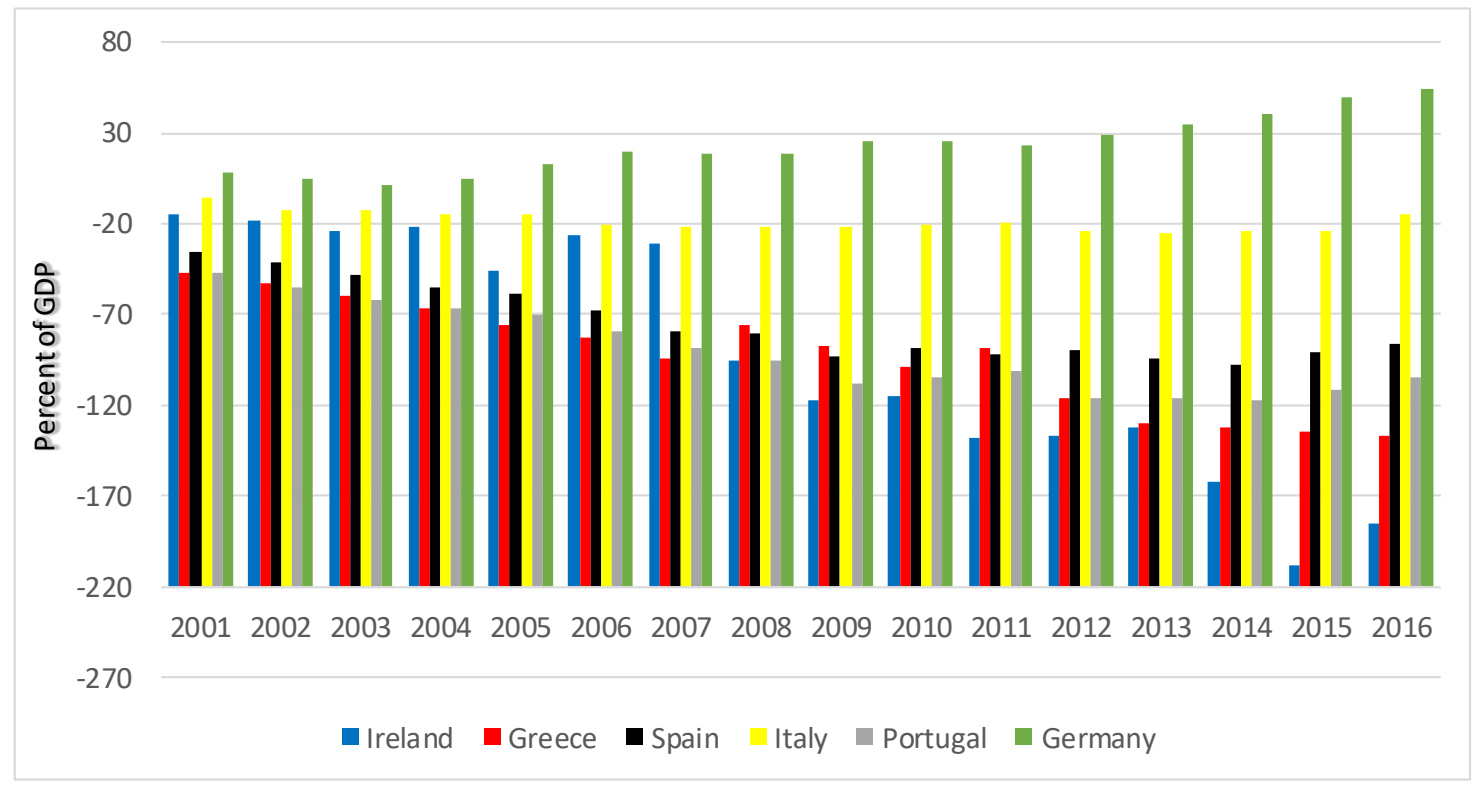

Source: Eurostat (2017). Elaborated by the authors.

The difficulty in recovering the economic growth of GIIPS can be ratified by the net financial position of the sectors of the economies, as we may observe in Table 3. The net financial position of a given sector is the difference between financial assets and financial liabilities of this same sector. The net position of the four sectors of the economy, namely, household $(\mathrm{H})$, government $(\mathrm{G})$, rest of the 
world (RW), and non-financial corporations (NFC), highlight an issue little discussed by orthodox economic theory and Eurozone authorities. This decomposition shows that, in the aggregate, the counterpart of the increase in the net asset of a given sector corresponds to the increase in the net liability, or to the decrease in net asset of other sector(s). With the reversal of capital flows, from 2007 and, mainly, 2008, a significant worsening of net financial position of households in GIIPS was verified, although they still remained with a surplus. In Germany, on the other hand, households presented improvement in their net financial position. In addition, the worsening of the net position of the government, although still occurring in GIIPS, goes against the determinations of the European authorities regarding the fiscal austerity. With the crisis, the rest of the world became the main counterpart in the decrease in the net financial position of households and the deterioration of the position of governments, in the case of GIIPS. Thus, the net financial position by sector presented in Table 3 shows the asymmetrically adjustment between sectors, in a comparison between GIIPS and Germany. In Germany, as shows the Table 3, the net financial position of the public sector increased less relative to GIIPS, with the counterpart of the private adjustment having strongly involved the rest of the world, different to GIIPS.

Table 3. Net financial position per sector, GIIPS and Germany (2000 - 2015, in US\$ billions)

\begin{tabular}{|c|c|c|c|c|c|c|c|c|}
\hline Sector & 2000 & 2007 & 2010 & 2015 & 2000 & 2007 & 2010 & 2015 \\
\hline & \multicolumn{4}{|c|}{ SPAIN } & \multicolumn{4}{|c|}{ GREECE } \\
\hline $\mathrm{H}$ & 697 & 950 & 789 & 1.280 & 194 & 218 & 110 & 137 \\
\hline G & -284 & -188 & -427 & -879 & -138 & -189 & -209 & -260 \\
\hline RW & 265 & 854 & 933 & 981 & 62 & 249 & 230 & 239 \\
\hline \multirow[t]{2}{*}{$\mathrm{NFC}$} & -693 & -1.623 & -1.446 & -1.359 & -105 & -211 & -125 & -152 \\
\hline & \multicolumn{4}{|c|}{ PORTUGAL } & \multicolumn{4}{|c|}{ ITALY } \\
\hline $\mathrm{H}$ & 129 & 172 & 176 & 211 & 2.546 & 3.130 & 2.749 & 3.200 \\
\hline G & -54 & -97 & -128 & -196 & -1.259 & -1.430 & -1.622 & -2.177 \\
\hline RW & 73 & 163 & 201 & 213 & 83 & 450 & 405 & 517 \\
\hline \multirow[t]{2}{*}{$\mathrm{NFC}$} & -141 & -243 & -241 & -233 & -1.254 & -2.083 & -1.869 & -1.993 \\
\hline & \multicolumn{4}{|c|}{ IRELAND } & \multicolumn{4}{|c|}{ GERMANY } \\
\hline $\mathrm{H}$ & 121 & 104 & 114 & 203 & 2.075 & 2.859 & 3.012 & 3.865 \\
\hline G & -14 & 0 & -80 & -152 & -764 & -1.044 & -1.267 & -1.296 \\
\hline RW & 20 & 62 & 191 & 531 & -57 & 57 & -313 & -1.182 \\
\hline NFC & -119 & -187 & -216 & -530 & -1.047 & -1.678 & -1.569 & -1.696 \\
\hline
\end{tabular}

Source: Eurostat (2017). Elaborated by the authors. Net financial position = Financial assets financial liabilities. 
Therefore, the adjustment dynamic of GIIPS shows the fallacy of the composition, to the extent that the search for debt reduction on the part of all sectors, including the government, combines to make deflationary adjustment inevitable. Moreover, by failing to act as a regional hegemonic center, Germany hinders the recovery of more fragile economies in the Eurozone (Oliveira, Deos and Wolf, 2012). According to Oliveira and Wolf (2017, p.160): "In order to avoid the deflationary adjustment, an intense cooperation system among superavit and deficit countries of the region, led by a hegemonic center [Germany] that is able to assume the functions of purchaser and lender of last resort, would be required."

\subsection{Overcoming the crisis}

We can say that the form of operation of European authorities during the Eurozone crisis is closely related to their vision regarding the determinants of this process. Based on theoretical orthodoxical assumptions, European authorities, under German leadership, pointed to the "fiscal irresponsibility" of GIIPS and the lack of competitiveness as the fundamental causes of the crisis, defending the adoption of austerity and the deepening of structural reforms (that is, flexibility in labour markets and health systems, pensions, social security, and education) as necessary actions to recovery and economic growth (Belluzzo, 2013). This becomes evident from Schäuble (2011), Finance Minister of Germany at the time, as well as in the various documents of the European Commission and the European Council.

In addition, according to Aglietta (2013), this diagnosis of the causes of the crisis, on the part of European authorities, allowed Germany to exempt itself from responsibility regarding its fundamental contribution to the imbalances created in the Eurozone, especially concerning the external accounts of the countries of the region.

Thus, Germany does not play the expected role of the hegemonic country of the bloc during crises, i.e., to act as an anticyclical economy to the other member countries (Oliveira and Wolf, 2017). Instead, the dynamics of its economy and the proposals of European authorities have not contributed to the growth and recovery in GIIPS (and in the Eurozone as a whole), but, indeed, inducing the dual effect of the decline of public expenditures and private demand, with the imposition of deflationary adjustment for countries in crisis (Belluzzo, 2013). The bailouts granted by Troika to GIIPS have involved strict conditionalities in terms of austerity policies and "structural reforms", emphasising this deflationary dynamic and hindering the economic recovery process. 
As we can observe in Graph 6, the thesis that the crisis of all the GIIPS countries resulted from "fiscal irresponsibility" is not supported. In the economic expansion period, between 2000-2007, the performance of Spain and Ireland is highlighted, since the countries showed a decrease in the general government gross debt in relation to GDP. It was from the global financial crisis triggered in 2008, with the decline of economic growth (a decrease in public revenues) and countercyclical policies and aid policies to the financial system (an increase in public expenditures), that a significant deterioration of the government finances of those countries was verified, even if with different intensities (Oliveira, Deos and Wolf, 2012). Hence, the strong fiscal deterioration observed after the crisis should be understood as a consequence, not the cause of the crisis. By 2016, only Ireland had been successful in a consistent reduction of the general government gross debt, highlighting the difficulties of this process for the other countries.

Graph 6. General government gross debt (Maastricht criterion), \% of GDP - GIIPS (2001-2016)

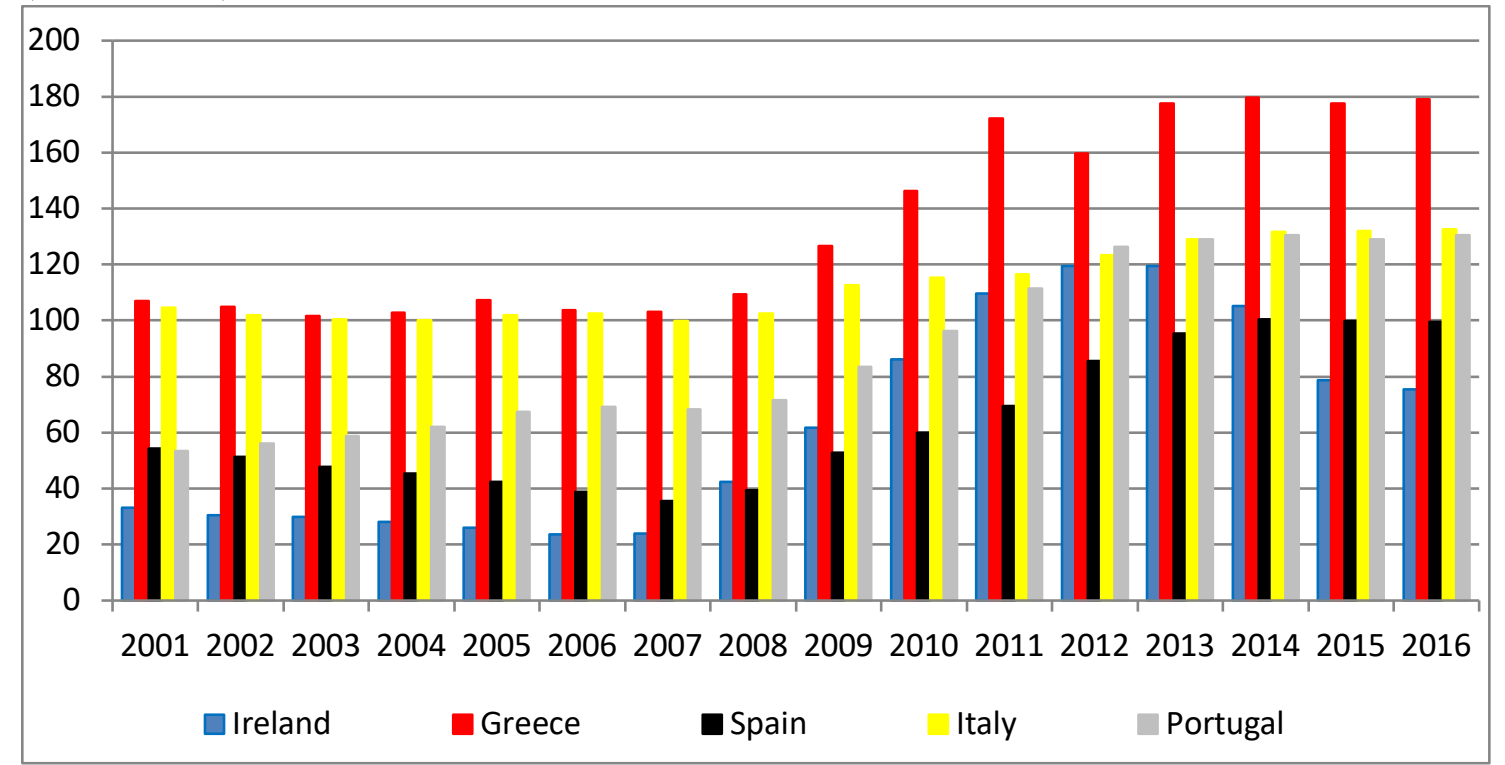

Fonte: Eurostat (2017). Elaborated by the authors.

\section{Conclusion and final remarks}

The evidence presented suggests that the economic crisis in the Eurozone resulted from growing internal imbalances that occurred in the region over the economic expansion period, particularly between the central member countries, with emphasis on Germany, and the peripheral countries of the region, namely GIIPS. Undeniably, it was potentialized by the way the Eurozone was established, under the restrictions imposed by the institutionality of the common currency on internal economic policies. As was analysed in this paper, the characteristics of the 
integration process and the influence of orthodox economic theories were very important for this conformation.

The conviction on the part of European authorities that the formation of the monetary union - according to the models proposed by the conventional orthodox theory - would be sufficient to provide the virtuous cycle proposed by the Lisbon Strategy generated internal imbalances to the region that were neglected during the favourable period. As soon as the reversal of the general state of expectations occurred, these imbalances became explicit.

Since then, the idea of accomplishing a monetary union based on orthodoxical theoretical assumptions focusing on liberalisation and financial deregulation, the single monetary policy, restrictions on national fiscal policies, the possibility of including heterogeneous countries in a bloc with the same currency, and the conceptions of real convergence of economies that are closer to wishful thinking than scientific arguments (such as the endogeneity criterion of New OCA) have come to be questioned in several academic and political circles, inside and outside of Europe.

However, European authorities, led by Germany, as well as much of the economic orthodoxy, insist on pointing out the causes of the crisis in the Eurozone, with its epicenter in GIIPS, as the result of "fiscal irresponsibility" and the lack of competitiveness on the part of these countries. When putting itself as an example of success to be followed, and not as one of those responsible for the crisis in the bloc, Germany creates a double setback for overcoming the crisis. On the one hand, it requires countries in crisis to follow its example, seeking increased external competitiveness, in search of external markets, but via deflationary adjustment, with stagnation of GDP internal determinants. On the other hand, by not admitting its active participation to the conformation of the crisis, the country does not see the need to cooperate, along with GIIPS, in order to overcome internal imbalances that were created. It is worth mentioning that the favourable economic performance of German exports over the expansion period was significantly influenced by the structure created by the Eurozone, with a strong increase in its exports to the countries of the region, with an emphasis on GIIPS. When requiring these countries to follow its example, it is necessary to find other external markets to absorb its exports, which reinforces the deflationary adjustment, because besides the context of low global growth and recession on the continent Mediterranean countries have each other and Germany itself as the greatest trading partners. 
Overcoming the crisis, in fact, imposes the need for a source of stimulus to the aggregate demand of GIIPS. With the impossibility of the performance of an autonomous expansionary fiscal policy and with the reticence of international financial markets to finance these economies, the prospects for the consistent recovery of economic growth are still very unencouraging, especially due to the impossibility of implementing countercyclical economic policies, as well as on account of the economic policies recommended by European authorities under German leadership. Therefore, the aggregate demand recovery of GIIPS requires that Germany assumes the function of lender and consumer of last resort in the region, in line with the arguments of Oliveira and Wolf (2017).

Last but not least, more work on this theme is necessary in considering alternative adjustment forms of recovering the aggregate demand of Eurozone countries and to explore these arguments in further detail, highlighting the GIIPS private debt crisis resulting from imbalances verified in GIIPS over the period of business cycle expansion.

\section{References}

Aglietta, M. (2013). Zona do Euro: Qual o Futuro? São Paulo: Editora Ideias \& Letras.

Alesina, A., Barro, R., \& Tenreyro, S. (2002). Optimum Currency Areas (NBER Working Papers No. 9072).

Amado, A. M., \& Mollo, M. de L. R. (2011). Ortodoxia e heterodoxia na discussão sobre integração regional: a origem do pensamento da CEPAL e seus desenvolvimentos posteriores. Estudos Econômicos (São Paulo), 34(1), 129-156. https://doi.org/10.1590/s0101-41612004000100005

Arestis, P. (2007). What is the New Consensus in Macroeconomics? In P. Arestis (Ed.), Is There a New Consensus in Macroeconomics? (pp. 22-42). New York: Palgrave Macmillan.

Arestis, P., \& Sawyer, M. (2011). The Design Faults of the Economic and Monetary Union. Journal of Contemporary European Studies, 19(1), 21-32.

Arestis, P., McCauley, K., \& Sawyer, M. C. (1999). From Common Market to Emu: A Historical Perspective of European Economic and Monetary Integration. Ssrn. https://doi.org/10.2139/ssrn.156554 
Athanassiou, E. (2012). Household debt and domestic demand: Greece versus other Euro Zone economics. International Journal of Business and Social Science, 3(10), 157-166.

Bakker, A. (1996). The liberalization of capital movements in Europe: the Monetary Committee and financial integration, 1958-1994. Amsterdam: Free University. $\quad$ Retrieved from http://books.google.ca/books? id=zEGxAAAAIAAJ

Belluzzo, L. (2013). Prefacio. In A. Martins \& M. Cintra (Eds.), As Transformaç̧ões no Sistema Monetario Internacional (pp. 9-18). Brasília: Instituto de Pesquisa Econômica.

Bernanke, B. S., \& Mishkin, F. S. (2011). Inflation Targeting: A New Framework for Monetary Policy? Journal of Economic Perspectives, 11(2), 97-116. https://doi.org/10.1257/jep.11.2.97

Bibow, J. (2012). The Euro Debt Crisis and Germany's Euro Trilemma (Levy Economics Institute Working Paper Collection No. 721). Levy Economics Institute Working Paper Collection.

Bibow, J. (2013). Germany and the Euroland Crisis: The Making of a Vulnerable Haven. Ssm. https://doi.org/10.2139/ssrn.2285612

Bresser-Pereira, L. C., \& Rossi, P. (2015). Sovereignty, the exchange rate, collective deceit, and the euro crisis. Journal of Post Keynesian Economics, 38(3), 355-375. https://doi.org/10.1080/01603477.2015.1087807

Corden, W. (1972). International Trade Theory and Policy. England: Edward Elgar Publishing Limited.

De Grauwe, P. (2010). The Financial Crisis and the Future of the Eurozone. Bruges European Economic Policy Briefings (Vol. 21).

De Grauwe, P., \& Mongelli, F. P. (2005). Endogeneities of optimum currency areas - what brings countries sharing a single currency closer together? ECB Working Paper Series. Retrieved from http://www.ecb.int/pub/pdf/scpwps/ecbwp468.pdf\%5Cnhttp://search.e bscohost.com/login.aspx?direct=true $\& \mathrm{db}=\mathrm{eoh} \& \mathrm{AN}=0820541 \&$ site $=$ ehos t-live

Delors Committee. (1989). Report on Economic and Monetary Union in the European Community. Luxembourg: Office for Official Publications of the European Communities. 
Dullien, S. (2010). Integração Produtiva na União Europeia: Uma Perspectiva Alemã. In R. Alvarez, M. Wohlers, \& R. Baumann (Eds.), Integracão Produtiva: Caminhos para o Mercosul (pp. 156-219). Brasilia: Agência Brasileira de Desenvolvimento Industrial.

Eichengreen, B. (2000). A Globalização do Capital. São Paulo: Editora 34.

Eichengreen, B. (2007). The European Economy Since 1945: Coordinated Capitalism and Beyond. Princeton and Oxford: Princeton University Press. European Commission (1990) "One Market, One Money: an Evaluation of the Potential Benefits and Costs of Forming an Economic and Monetary Union" European Economy, n. 44, 341p.

European Statistical System (Eurostat) (2017) Database. Brussels: European Commission.

Fitzgerald, J. (2014). Ireland's recovery from crisis. CESifo Forum, 15(2), 8-13.

Flassbeck, H., \& Lapavitsas, C. (2013). The Systemic Crisis of the Euro - True Causes and Effective Therapies. Berlin: Rosa Luxemburg Stiftung.

Frankel, J. A., \& Rose, A. K. (1997). Is EMU more justifiable ex post than ex ante? European Economic Review, 41(3-5), 753-760. https://doi.org/10.1016/S0014-2921(97)00034-2

Emerson, M., Gros, D., \& Italianer, A. (1992). One Market, One Money: An Evaluation of the Potential Benefits and Costs of Forming an Economic and Monetary Union. Oxford University Press.

European Commission (1990). One Market, One Money: an Evaluation of the Potential Benefits and Costs of Forming an Economic and Monetary Union. (European Economy, n. 44). Dictorate-General for Economic and Financial Affairs of the Commission of European Communities.

Goodfriend, M., \& King, R. (1997). The New Neoclassical Synthesis and the Role of Monetary Policy. In B. Bernanke \& J. Rotemberg (Eds.), NBER Macroeconomics Annual (pp. 231-296). Cambridge, MA: MIT Press.

Guttmann, R., \& Plihon, D. (2010). Consumer debt and financial fragility. International Review of Applied Economics, 24(3), 269-283. https://doi.org/10.1080/02692171003701420

Hein, E. (2012). The Macroeconomics of Finance-Dominated Capitalism - and its Crisis. Northampton: Edward Elgar. https://doi.org/10.4337/9781781009161 
Helleiner, E. (1994). States and the Reemergence of Global Finance: from Bretton Woods to the 1990's. Ithaca and London: Cornwell University Press.

International Monetary Fund (IMF) (2017) World Economic Outlook Database. Washington, DC: IMF.

Ishiyama, Y. (1975). The Theory of Optimum Currency Areas: a Survey (IMF Staff Papers No. 22).

Issing, O., Angeloni, I., Gaspar, V., \& Tristani, O. (2004). Monetary Policy in the Euro Area: Strategy and Decision Making at the European Central Bank. Cambridge: Cambridge University Press.

Judt, T. (2017). Postwar: A History of Europe Since 1945. New York: Penguin Press. https://doi.org/10.4324/9781912281541

Keynes, J. M. (1936). The General Theory of Employment, Interest and Money. New York, NY: Harcourt, Brace.

Kydland, F. E., \& Prescott, E. C. (1977). Rules Rather than Discretion: The Inconsistency of Optimal Plans. Journal of Political Economy, 85(3), 473491. https://doi.org/10.1086/260580

Minsky, H. (1982). Can "It"' Happen Again? Essays on Instability and Finance." New York: M. E. Sharpe.

Minsky, H. (1986). Stabilizing an Unstable Economy. New Haven: Yale University Press.

Miranda, J. (2014). Três Ensaios sobre a Integração Europeia. In A. Biancarelli, A. Calixtre, \& M. Cintra (Eds.), Presente e Futuro do Desenvolvimento Brasileiro (pp. 543-594). Brasilia: Instituto de Pesquisa Econômica Aplicada.

OECD (2016). OECD Factbook 2015-2016: Economic, Environmental and Social Statistics. Paris: OECD Publishing.

Oliveira, G., \& Wolf, P. (2017). The Euro and the Recent European Crisis vis-à-vis the Gold Standard and the Great Depression: Institutionalities, Specificities and Interfaces. Brazilian Journal of Political Economy, 37(1), 147-166.

Oliveira, G., Deos, S., \& Wolf, P. (2012). A Crise Europeia e os Limites do Ajuste Deflacionario. In D. Modenesi, D. Prates, J. Oreiro, L. F. Paula, \& M. Resende (Eds.), Sistema Financeiro e Política Econômica em uma Era de Instabilidade (pp. 30-42). Rio de Janeiro: Elsevier. 
Oliveira, G., Deos, S., \& Wolf, P. (2014). Integração Regional e Convergência Econômica Real: Lições da Experiência Europeia. Analise Econômica, 32(61), 7-40.

Priewe, J. (2012). European Imbalances and the Crisis of the European Monetary Union. In From Crisis to Growth? - Conference of Research Network Macroeconomics and Macroeconomic Policies (FMM). Berlin.

Robson, P. (1998). The Economics of International Integration (4th ed.). London: New Fetter Lane.

Schauble, W. (2011, September 5). Why austerity is the Only Cure for the Eurozone. Financial Times, September.

Scheller, H. (2006). O Banco Central Europeu - História, Papel e Funções. Frankfurt: Banco Central Europeu.

Tavlas, G. S. (1993). The 'New' Theory of Optimum Currency Areas. World Economy, 166), 663-685. https://doi.org/10.1111/j.14679701.1993.tb00189.x

Toporowski, J. (2013). International credit, financial integration and the euro. Cambridge Journal of Economics, 37(3), 571-584. https://doi.org/10.1093/cje/bet008

Werner Report (1970). Report to the Council and the Commission on the Realization by Stages of Economic and Monetary Union in the Community. Luxembourg: Commission of the European Communities. 